\title{
Retention Force of T-bar Clasps for Titanium and Cobalt-Chromium Removable Partial Dentures
}

\author{
Renata Cristina Silveira RODRIGUES \\ Ana Paula MACEDO \\ Érica Miranda de TORRES \\ Maria da Glória Chiarello de MATTOS \\ Ricardo Faria RIBEIRO \\ Department of Dental Materials and Prosthodontics, Dental School of Ribeirão Preto, \\ University of São Paulo, Ribeirão Preto, SP, Brazil
}

\begin{abstract}
The objective of this study was to evaluate the retention force of T-bar clasps made from commercially pure titanium $(\mathrm{CP} \mathrm{Ti})$ and cobalt-chromium $(\mathrm{Co}-\mathrm{Cr})$ alloy by the insertion/removal test simulating 5 years use. Thirty-six frameworks were cast from $\mathrm{CP} \mathrm{Ti}$ $(\mathrm{n}=18)$ and $\mathrm{Co}-\mathrm{Cr}$ alloy $(\mathrm{n}=18)$ with identical prefabricated patterns on refractory casts from a distal extension mandibular hemi-arch segment. The castings were made on a vacuum-pressure machine, under vacuum and argon atmosphere. Each group was subdivided in three, corresponding to $0.25 \mathrm{~mm}, 0.50 \mathrm{~mm}$ and $0.75 \mathrm{~mm}$ undercuts, respectively. No polishing procedures were performed to ensure uniformity. The specimens were subjected to an insertion/removal test and data was analyzed statistically to compare CP Ti and Co$\mathrm{Cr}$ alloy in the same undercut (Student's t-test for independent samples) and each material in different undercuts (one-way ANOVA) $(\mathrm{p}=0.05)$. Comparisons between materials revealed significant differences $(\mathrm{p}=0.017)$ only for the 0.50 -mm undercut. No significant differences $(p>0.05)$ were found when comparing the same material for the undercuts. It may be concluded that for different undercuts, both Co-Cr alloy and CP Ti had no significant differences for T-bar clasps; CP Ti showed the lowest retention force values when compared to Co-Cr alloy in each undercut, but with significant difference only for the 0.50 -mm undercut; and both materials maintained the retentive capacity during the simulation test.
\end{abstract}

Key Words: titanium, dental clasps, denture retention, denture, partial, removable, chromium alloys.

\section{INTRODUCTION}

Since the introduction of lost-wax casting, various metals have been tested for the fabrication of removable partial denture (RPD) frameworks. Gold and cobalt-chromium (Co-Cr) alloys are among the most frequently used materials. Despite the improvements made to Co-Cr alloys and the fact that these alloys are the most used for casting RPD metallic frameworks, the search for a material with the ideal properties for fabricating RPD remains a matter of concern and the use of titanium for the production of cast RPD framework has gradually increased (1-4).

On the past few years, various materials have been tested for RPD casting and, especially over the last decade, several studies have highlighted the advantages of titanium and titanium alloys, and have investigated their possible use in the fabrication of RPD metallic frameworks (4-9).

In addition to its remarkable biocompatibility, the low modulus of elasticity is another property that makes titanium more resilient and, therefore, more similar to gold alloys. This property allows for placing clasps in larger retentive areas, without applying excessive loads to abutment teeth during denture insertion and removal, thus favoring esthetics $(10,11)$. However, more studies are necessary to investigate the permanent deformations, which are one of the most common mechanical complications that affect denture clasps due to the possibility of causing loss of denture retention and stability (12).

Correspondence: Profa. Dra. Renata Cristina Silveira Rodrigues, Departamento de Materiais Dentários e Prótese, Faculdade de Odontologia de Ribeirão Preto, Universidade de São Paulo, Avenida do Café, s/n, Monte Alegre, 14040-904 Ribeirão Preto, SP, Brasil. Tel: +55-163602-4005. Fax: 16-3633-0999. e-mail: renata@forp.usp.br 
In spite of the several advancements brought about by new casting machines, there is still no problem-free technology. Porosity and inadequate mold filling are frequently observed problems in titanium casting $(4,9)$.

Several studies on the fabrication of commercially pure titanium (CP Ti) and titanium alloy clasps have shown that these clasps are suitable, since they maintain retentive capacity. Nonetheless, further studies are needed to confirm their feasibility in the long term $(4,9,11,13)$. In addition, most studies evaluated the retentive capacity of circumferential clasps, but other clasp designs $(14,15)$ should be tested to prove titanium suitability as a material of choice.

The objective of this study was to evaluate the retention force of T-bar clasps made from CP Ti or Co$\mathrm{Cr}$ alloy using three different undercut areas $(0.25-$, 0.50 - and $0.75-\mathrm{mm})$.

\section{MATERIAL AND METHODS}

In order to perform the use simulation test, three metallic matrices, representing a distal extension mandibular right hemi-arch segment, were fabricated from Co-Cr alloy (Fig. 1A). The first, second and third matrices provided undercuts of $0.25-\mathrm{mm}(0.01-\mathrm{inch})$, 0.50-mm (0.02-inch), and 0.75-mm (0.03-inch), respectively, in the test positions established for T-bar clasps. In addition, a mesial occlusal rest and proximal and lingual guide-planes were prepared on the 2nd premolar, to standardize the path of insertion.

The matrices were relieved for the correct waxing of the frameworks and duplicated in silicone (Elite Double, Zhermack S.p.A., Rovigo, Italy). Casts with
Rematitan Plus (Dentaurum, Pforzheim, Germany) were used to make the CP Ti test specimens, and casts with Crom-O-Cast (Polidental Industry and Commerce Ltd., São Paulo, Brazil) were used to make the Co-Cr alloy test specimens.

To standardize the study, prefabricated T-bar clasp patterns (Rewax, Renfert GmbH, Hilzingen, Germany) were positioned on the casts, which were attached to a plastic pin (5-mm wide and 30-mm long), positioned on a circular retention mesh (Renfert $\mathrm{GmbH}$ ) in the area corresponding to the distal extension partial denture base. This pin originally served as a sprue for the molten alloy and, secondly, it was used to position the specimens in the simulation test machine.

A total of 36 specimens were cast (18 for each material, divided in 3 subgroups corresponding to the tested undercuts) in the Discovery Plasma machine (EDG Equipments and Controls Ltd., São Carlos, SP, Brazil), which casts metal by plasma with injection by vacuum-pressure. The following metals were used: $\mathrm{CP}$ Ti (Tritan grade I; Dentaurum, Pforzheim, Germany) and Co-Cr alloy (Remanium GM 380; Dentaurum).

After casting, the specimens were removed from the cast and subject to $100-\mu \mathrm{m}$ aluminum oxide particle air abrasion $\left(80 \mathrm{psi}-5.62 \mathrm{kgf} / \mathrm{cm}^{2}\right)$. To ensure uniformity in terms of clasp dimension, nodules and burs were carefully removed with tungsten burs under magnification, when necessary. Co-Cr specimens were subject to electrolytic polishing in a VRC apparatus (R.R. Equipments for Dental Prostheses Ltd., São Paulo, SP, Brazil). CP Ti specimens were subject to chemical polishing, i.e., soaking in Kroll solution (10$\mathrm{mL} \mathrm{HF}, 30-\mathrm{mL} \mathrm{HNO}_{3}$ and 50-mL water) for $1 \mathrm{~min}$.

In order to perform the insertion/removal simu-
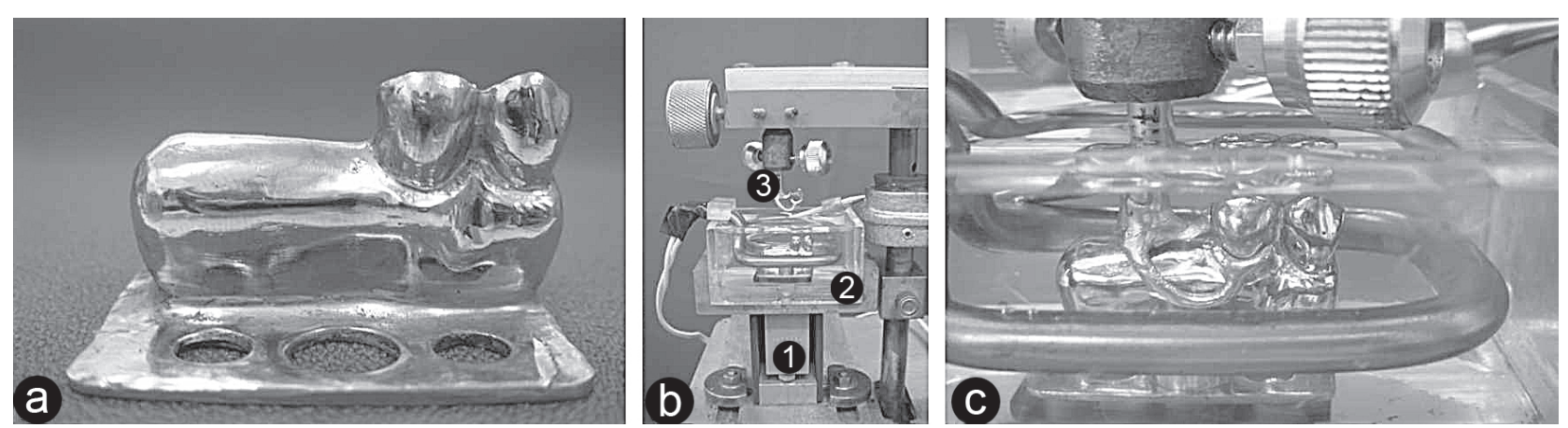

Figure 1. Set for simulation test: A) Matrix of right mandibular hemi-arch; B) Main testing apparatus: 1) Load cell; 2) Metallic matrix; 3) Specimen; C) Specimen during the insertion/removal cycle. 
lation test, a testing apparatus was used (Fig. 1B), designed at the Department of Dental Materials and Prosthodontics of the Dental School of Ribeirão Preto, University of São Paulo, Brazil (9). The apparatus allowed for the insertion of the metallic framework into its terminal position on the $\mathrm{Co}-\mathrm{Cr}$ matrices and its subsequent removal, thus simulating the placement and removal of an RPD. Tests were performed in a wet environment at $37 \pm 5^{\circ} \mathrm{C}$ (Fig. 1C).

To analyze the data obtained during the simulation test, intervals corresponding to $0,1 / 2,1,2,3,4$ and 5 years were established. A total of 7,205 cycles were performed, representing the simulated insertion and removal of the RPD over 5 years, estimating that the patient would perform 4 complete cycles per day. The test was performed with 41 cycles/min at a constant speed of $35.79 \mathrm{~mm} / \mathrm{s}$. The value established for each time interval corresponded to the arithmetic average of 10 consecutive insertion/removal cycles. The force required for each specimen removal was captured and stored using data acquisition software (LabView 5.0.1, National Instruments, Austin, USA).

The obtained data was submitted to statistical analysis using the SPSS 12.0 software (SPSS Inc., Chicago, IL, USA) to compare CP Ti and Co-Cr alloy in the same undercut (Student's t-test for independent samples) and each material in different undercuts (oneway ANOVA). Significance level was set at $5 \%$.

\section{RESULTS}

For the $0.25-\mathrm{mm}$ and $0.75-\mathrm{mm}$ undercuts, there were no statistically significant differences $(p>0.05)$ between $\mathrm{Co}-\mathrm{Cr}$ and $\mathrm{CP}$ Ti. However, statistically significant differences $(p=0.0175)$ were found for the 0.50-mm undercut.

Comparing the same alloy for the three undercuts, no statistically significant differences were observed for Co-Cr $(p=0.293)$ or CP Ti $(p=0.062)$.

Regarding the behavior of the materials (Fig. 2), $\mathrm{CP}$ Ti specimens showed smaller retentive force than Co-Cr for all undercuts ( $p=0.200$ for $0.25-\mathrm{mm}$; $p=0.017$ for $0.50-\mathrm{mm} ; \mathrm{p}=1.000$ for $0.75-\mathrm{mm}$ ). Analyzing the Co$\mathrm{Cr}$ alloy during the test, the different undercuts showed no significant differences $(p>0.05)$ and had a slight increase in retention force from the beginning to the end of the simulation test. For CP Ti, although there were no significant differences $(p>0.05)$ for the tested undercuts, there was a slight increase in retention force for the $0.50-\mathrm{mm}$ and $0.75-\mathrm{mm}$ undercuts, and a slight decrease for the $0.25-\mathrm{mm}$ undercut during the simulation test.

\section{DISCUSSION}

Several studies have tested the use of CP Ti in the fabrication of RPD metallic frameworks, mainly regarding clasp retention. Although authors have observed that CP Ti maintains the retentive capacity, most of these studies were focused on circumferential clasps $(9,11)$ and no work was found about T-bar clasp design. Ohkubo (4) stated that titanium RPD frameworks have never been reported to fail dramatically.

This study aimed to verify the behavior of T-bar clasps in terms of their retentive capacity, simulating five years of metallic framework use with different undercuts $(0.25-\mathrm{mm}, 0.50-\mathrm{mm}$, and $0.75-\mathrm{mm})$. The $0.25-\mathrm{mm}$ undercut is justified by its recommendation for Co-Cr clasps, and the $0.50-\mathrm{mm}$ undercut is supposed to be frequently used in dental clinics. Although there is evidence of the $0.75-\mathrm{mm}$ undercut being contraindicated for Co-Cr alloys, there are reports stating that larger undercuts could be used for CP Ti $(10,11)$, which explains its use in this study.

The design of the clasp assembly used is also based on the observation that T-bar clasp retentive arm with rigid reciprocal arm and a mesial rest were a frequently used design for distal extension RPD (14) and that improvement of bracing by adding a distal guide plane and widening bracing arm is recommended

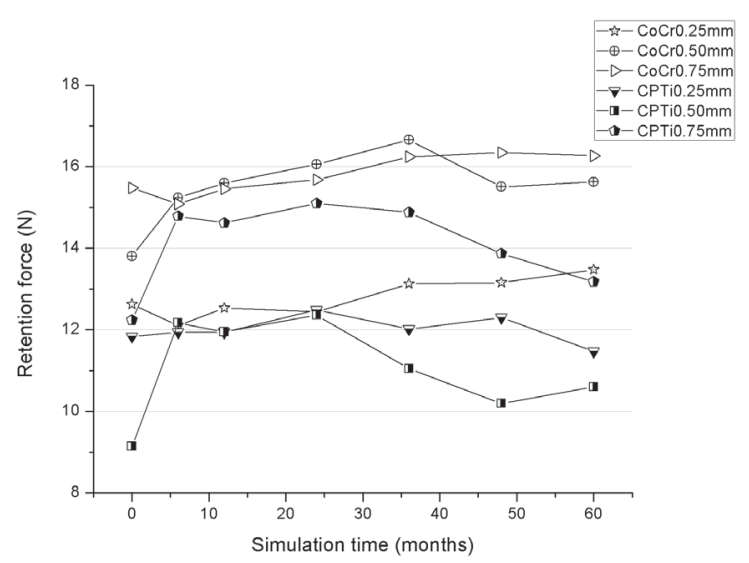

Figure 2. Comparison between CP Ti and Co-Cr alloy clasps under different undercuts. 
(15).

In the present study, differences $(\mathrm{p}=0.017)$ were found between $\mathrm{Co}-\mathrm{Cr}$ and $\mathrm{CP}$ Ti only for the $0.50-\mathrm{mm}$ undercut. In the other conditions, although $\mathrm{Co}-\mathrm{Cr}$ consistently showed greater retention compared to $\mathrm{CP} \mathrm{Ti}$, no significant differences were observed.

Figure 2 shows that $\mathrm{Co}-\mathrm{Cr}$ and $\mathrm{CP}$ Ti clasps do not lose retention over time, both showing a slight tendency to increase retention force values from the beginning to the end of the simulation test, but without significant differences ( $p>0.05$ ). As expected, $\mathrm{Co}-\mathrm{Cr}$ alloy showed greater force values throughout the insertion/removal simulation test when compared to CP Ti. It was observed that there was little variation in the retention force values, except for the initial period of the $0.50-\mathrm{mm}$ undercut. For the $0.25-\mathrm{mm}$ undercut, the recommended type of retention for this alloy, the retention force values were close to those of $\mathrm{CP} \mathrm{Ti}$ with 0.75-mm undercut.

For $\mathrm{CP} \mathrm{Ti}$, the behavior during the test was similar, and no significant differences $(\mathrm{p}>0.05)$ were observed. The retention force values for the $0.50-\mathrm{mm}$ undercut showed the highest variation during the test, but no consistent explanation could be offered for this fact. Some additional tests must be taken to confirm these results.

No fractures were detected on the specimens during the test, including those under the $0.75-\mathrm{mm}$ undercut. It must be emphasized that the tests always followed the path of insertion until reaching the terminal position of the framework, which was ensured by the guide-planes prepared on the abutment teeth and by the testing apparatus, both assuring that no torsion was applied to the framework and clasps. It is also relevant that the test did not include specimens presenting structural defects, such as internal porosities.

Despite the good physical and mechanical properties of this Co-Cr alloy, the search for a material with ideal properties continues. In this regard, interest in using $\mathrm{CP} \mathrm{Ti}$ to fabricate RPD frameworks has increased $(2,4)$. CP Ti has several advantageous properties. Especially for RPD, the most valuable are its low density, which allows for the fabrication of light frameworks, low modulus of elasticity, which permits using larger undercuts, and its remarkable biocompatibility $(4,10)$. In spite of the good physical and mechanical properties of $\mathrm{CP} \mathrm{Ti}$, high cost and casting difficulties still pose limits to its use $(4,16-18)$.
In this study, castings were performed by plasma, under vacuum and argon-inert atmosphere, with the metal/alloy injected by vacuum pressure. The casting temperatures used were $950^{\circ} \mathrm{C}$ for Co-Cr alloy and $430^{\circ} \mathrm{C}$ for $\mathrm{CP} \mathrm{Ti}$. Thermal cycles were performed following the exact recommendation of the investment manufacturers, especially for $\mathrm{CP} \mathrm{Ti}$, avoiding surface reactions with the investment material.

The dimensions of commercially available wax patterns should also be discussed. Thomas et al. (19) consider that there is no reason for changes in the designs of CP Ti frameworks in order to obtain rigidity, while clasp dimensions for $\mathrm{Co}-\mathrm{Cr}$ alloy should be reduced, but casting conditions do not allow for this reduction to occur. The authors highlight that commercially available wax patterns usually applied for Co-Cr alloys were designed for gold alloys, which have elastic modulus of $90 \mathrm{GPa}$, similar to that of CP Ti (85$105 \mathrm{GPa})$. The results obtained in this study assure that these materials could be used in the fabrication of T-bar clasps for RPD, since both maintained an adequate retentive capacity throughout the period of insertion/ removal simulation.

The increase of retention force observed for the clasps in this study could be consequence of strain hardening. On the other hand, residual stresses after the deflection decreases the mechanical strength of the metal/alloy and could induce permanent deformation or fracture of clasps arms $(3,11,13)$.

Considering the limitations of this study, further studies are needed, in conditions closer to those of clinical situations, since the abutment tooth used in this study was of a rigid system, ensured by the construction of the test matrix, using effective guide-planes. On the other hand, under clinical conditions, the periodontal ligament is present, which allows for small tooth movement. This movement might lead to tooth adjustment, to a greater or lesser extent, depending on a number of factors, such as clasp force, possibly reducing the resultant forces (9). In the mouth, there are usually different insertion and removal paths, since obtaining truly effective guide-planes is conditioned by anatomical aspects. Additionally, patients can change the path used to move the denture at each insertion and/ or removal cycle, producing greater loads on the tooth, thus leading to permanent clasp defects in a short period of time (21).

Other limitation is related to technical problems 
associated with $\mathrm{CP}$ Ti casting process, and new studies are needed to minimize that. Further research is needed before CP Ti can be safely indicated for the fabrication of RPD. Also, despite the materials could be appropriate for removable partial denture framework fabrication, other investigation about properties and clinical requirements for these materials must be made.

Under the tested conditions, it may be concluded that: 1 . For different undercuts, both Co-Cralloy and CP Ti had no significant differences for T-bar clasps; 2. CP $\mathrm{Ti}$ showed the lowest retention force values when compared to Co-Cr alloy in each undercut, but without significant difference only for the 0.50 -mm undercut; 3 . Both materials maintained the retentive capacity during the simulation test.

\section{RESUMO}

O objetivo deste estudo foi avaliar a força de retenção de grampos tipo barra T confeccionados em titânio cp e liga de Co-Cr, através do ensaio de simulação de uso de estruturas metálicas por um período de 5 anos. Sobre modelos de revestimento que simulavam uma extremidade livre unilateral, foram fundidas 36 estruturas em titânio cp $(\mathrm{n}=18)$ e em Co-Cr $(\mathrm{n}=18)$ utilizando padrões préfabricados. As fundições foram feitas em máquina de vácuopressão sob vácuo e atmosfera inerte de argônio. Cada grupo foi subdividido em três correspondendo às retenções de $0,25 \mathrm{~mm}$, $0,50 \mathrm{~mm}$ e $0,75 \mathrm{~mm}$, respectivamente. Para manter a uniformidade dos grampos, não foram realizados procedimentos de polimento. Os corpos-de-prova foram submetidos ao teste de inserção e remoção e os dados foram analisados estatisticamente $(\mathrm{p}=0,05)$ para comparar Ti cp e Co-Cr na mesma retenção (teste $\mathrm{T}$ de Student para amostras independentes) e cada material nas diferentes retenções (análise de variância a um fator). A comparação entre os materiais revelou diferença significativa apenas para retenção de $0,50(\mathrm{p}=0,017)$. Não foram encontradas diferenças quando se comparou o mesmo material nas diferentes retenções $(p>0,05)$. Pode-se concluir que para as diferentes retenções, grampos barra $\mathrm{T}$ confeccionados em liga de $\mathrm{Co}-\mathrm{Cr} \mathrm{e}$ titânio não apresentaram diferença estatisticamente significante; o titânio apresentou menores valores de retenção quando comparado à liga de $\mathrm{Co}-\mathrm{Cr}$ em cada uma das retenções, mas diferença estatisticamente significante só foi encontrada para a retenção 0,50-mm; e ambos materiais mantiveram a capacidade retentiva durante o teste de simulação de uso.

\section{ACKNOWLEDGEMENTS}

To FAPESP for financial support (grant \# 05/58363-5) and to Mr. Marcelo Aparecido Vieira for his valuable technical assistance.

\section{REFERENCES}

1. Kononen M, Rintanen J, Waltimo A, Kempainen P. Tita- nium framework removable partial denture used for patient allergic to other metals: a clinical report and literature review. J Prosthet Dent 1995;73:4-7.

2. Iwama CY, Preston JD. Cobalt-chromium-titanium alloy for removable partial dentures. Int J Prosthodont 1997;10:309317.

3. Bridgeport DA, Brantley WA, Herman PF. Cobalt-Chromium and Nickel-Chromium Alloys for Removable Prosthodontics, Part 1: Mechanical Properties. J Prosthodont 1993;2:144-150.

4. Ohkubo C, Hanatani S, Hosoi T. Present status of titanium removable dentures - a review of the literature. J Oral Rehabil 2008.

5. Blackman R, Barghi N, Tran C. Dimensional changes in casting titanium removable partial dentures frameworks. J Prosthet Dent 1991;65:309-315.

6. Vallittu PK, Kokkonen M. Deflection fatigue of cobalt-chromium, titanium, and gold alloy cast denture clasp. J Prosthet Dent 1995;74:412-419.

7. Wang RR, Fenton A. Titanium for prosthodontic applications: a review of the literature. Quintessence Int 1996;27:401-408.

8. Kotake M, Wakabayashi N, Ai M, Yoneyama T, Hamanaka H. Fatigue resistance of titanium-nickel alloy cast clasps. Int $\mathbf{J}$ Prosthodont 1997; 10:547-552.

9. Rodrigues RCS, Ribeiro RF, Mattos MGC, Bezzon OL. Comparative study of circumferential clasp retention force for titanium and cobalt-chromium removable partial dentures. J Prosthet Dent 2002;88:290-296.

10. Lautenschlager EP, Monaghan P. Titanium and titanium alloys as dental materials. Int Dent J 1993;43:245-253.

11. Bridgeman JT, Marker VA, Hummel SK, Benson BW, Pace LL. Comparison of titanium and cobalt-chromium removable partial denture clasps. J Prosthet Dent 1997;78:187-193.

12. Mahmoud AA, Wakabayashi N, Takahashi H. Prediction of permanent deformation in cast clasps for denture prostheses using a validated nonlinear finite element model. Dent Mater 2007;23:186-193.

13. Mahmoud A, Wakabayashi N, Takahashi H, Ohyama T. Deflection fatigue of Ti-6Al-7Nb, Co-Cr, and gold alloys cast clasps. J Ptrosthet Dent 2005;93:183-188.

14. Jorge JH, Giampaolo ET, Vergani CE, Machado AL, Pavarina AC, Cardoso de Oliveira MR. Clinical evaluation of abutment teeth of removable partial denture by means of the Periotest method. J Oral Rehabil 2007;34:222-227.

15. Yamamori T. Design of removable partial denture. Nihon Hotetsu Shika Gakkai Zasshi 2007;51:241-249.

16. Mori T, Togaya T, Jean-Louis M, Yabugami M. Titanium for removable dentures. I. Laboratory procedures. J Oral Rehabil 1997;24:338-341.

17. Jang K-S, Youn S-J, Kim Y-S. Comparison of castability and surface roughness of commercially pure titanium and cobaltchromium denture frameworks. J Prosthet Dent 2001;86:93-98.

18. Hung CC, Hou GL, Tsai CC, Huang CC. Pure titanium casting into zirconia-modified- magnesia- based investment molds. Dent Mater 2004;20:846-851.

19. Thomas CJ, Lechner S, Mori T. Titanium for removable dentures. II. Two year observation. J Oral Rehabil 1997;24:414418 .

20. Bezzon OL, Mattos MGC, Ribeiro RF. Surveying removable partial dentures: the importance of guiding planes and path of insertion for stability. J Prosthet Dent 1997;78:412-418.

Accepted July 21, 2008

Braz Dent J 19(3) 2008 